MARCELINA JAKIMOWICZ

Uniwersytet Medyczny im. Piastów Śląskich we Wrocławiu (Muzeum Farmacji)

\title{
Trauma świadka, trauma ofiary? Holokaust i antypolska akcja w pamięci osób urodzonych w Galicji Wschodniej
}

$W_{\text {sowanej broni czy powstałych zniszczeń, ale także w sensie socjologicz- }}^{\text {ojna nowoczesna ma charakter totalny - nie tylko w odniesieniu do sto- }}$ nym. Jej uczestnicy łatwo ulegają oddziaływaniu grupy, czego konsekwencją są stany masowego podniecenia, które prowadzą do grabieży, gwałtów, niszczenia cennych zabytków kultury, pogromów ludności cywilnej, linczów, tortur (Gruszyński 2016: 158). Syndrom wojenny wiąże się z emocjonalną niestabilnością, powracającymi stanami napięcia, silnymi uczuciami depresyjnymi i lękowymi. Psychiatra Maria Orwid zaznacza, że ludzie, którzy brali udział w wojnie jako sprawcy, ofiary czy także bierni świadkowie, „połączeni są czymś na kształt bardzo ponurego i przewrotnego romansu" (Orwid 2009: 11). Wojna, jak i wydarzenia będące jej konsekwencjami, takie jak: zmiany granic i powojenne migracje, są jednocześnie doświadczeniem jednostkowym i kolektywnym. Mimo że każdy kto przeżył wojnę ma własne tragiczne doświadczenia, może przeżywać je wspólnie z innymi uczestnikami, wplatając swoje wspomnienia w ramy identycznych okoliczności wojennych (Rokuszewska-Pawełek 2002: 131). Tego rodzaju doświadczenia niewątpliwie mają charakter graniczny, czyli - jak pisał Hans-Georg Gadamer - dzielą życie na „przedtem” i „potem”, uświadamiają ludzką skończoność, są wydarzeniami, na które nikt nie może być przygotowany (Gadamer 1993: 332-333). Opowieści i wielkie narracje dotyczące cierpienia pomagają oswoić się z tragicznością ludzkiego życia; są totalne, ponieważ dotykają każdego żyjącego w tym czasie człowieka. Wielkie narracje uodparniają na 
tragizm, osłabiają lęki, przynoszą ulgę bądź pozwalają odnaleźć zagubiony sens (Straś-Romanowska 2010: 35). Narracje biograficzne osób, które przeżyły wojnę, zawierają wspomnienia doświadczeń niepowtarzalnych i indywidualnych, jednak nie wszystkie z nich są doświadczeniem traumatyzującym.

Prowadząc przez kilka lat badania do pracy doktorskiej, a także współpracując z Ośrodkiem „Pamięć i Przyszłość” we Wrocławiu przy projektach dotyczących relacji świadków historii, wykorzystywałam narzędzie badawcze, jakim jest wywiad biograficzny ${ }^{1}$ Spotkałam się z wieloma ludźmi, którzy przeżyli i pamiętali II wojnę światową, prowadziłam badania w Polsce (Dolny Śląsk) i na terenach Ukrainy Zachodniej. W niniejszym artykule będę opierać się na opowieściach osób przesiedlonych po wojnie z Galicji Wschodniej na teren Dolnego Śląska, a także tych, którzy nie skorzystali z możliwości wyjazdu, dziś są więc obywatelami niepodległej Ukrainy. Podczas prowadzenia wywiadów wielokrotnie zastanawiałam się, czy moje pytania oraz chęć wysłuchania całej opowieści życia nie pogłębiają u rozmówców traumatycznych wspomnień, nie „rozdrapują zabliźnionych ran”. Nie chcąc szkodzić, starałam się zapoznać z pojęciem traumy². Ponieważ nie jestem psychologiem czy psychiatrą, musiałam sięgnąć do opracowań z tych dziedzin. Bazując na własnych badaniach terenowych, w ramach tekstu zastanawiam się nad różnymi obliczami wojennej traumy na przykładzie bycia świadkiem Holokaustu, a zarazem doświadczającym antypolskiej akcji.

Artykuł oparty jest na 25 narracjach biograficznych osób urodzonych w międzywojniu na terenie Galicji Wschodniej - obywateli polskich i ukraińskich ${ }^{3}$. Analizując narracje w kontekście traumy, zauważyłam, że w obu grupach pojawiały się dwa wydarzenia, które w większości relacji były ze sobą powiązane: bycie biernym świadkiem Holokaustu, jak i doświadczenie przeżycia antypolskiej akcji. Co interesujące, rozmówcy łączyli oba wydarzenia, Holokaust w strukturze narracji był „preludium” do opowieści o strachu czy też ocaleniu z antypolskiej akcji. Dlatego też w tekście zastanawiam się, w jaki sposób oba wydarzenia wpłynęły na pamięć rozmówców i jakie mają dla nich znaczenie. Oba wydarzenia traktuję jako czynniki traumatyzujące rozmówców i mające duży wpływ na ich tożsamość.

\footnotetext{
Wywiad biograficzny - jedna z technik badawczych badań nad biografią. Jej celem jest uzyskanie opowieści o życiu, która nie jest zakłócona interwencją badacza. Wywiad składa się z kilku faz, najważniejsza jest faza narracji, która ma na celu uzyskanie spontanicznej, niezakłóconej przez badacza opowieści o życiu. Dopiero po jej zakończeniu następuje chwila, w której badacz może zapytać o wątpliwe pojęcia, tematy szczególnie go interesujące, pytania o opinie i komentarze. Fritz Schütze zaproponował nie tylko technikę prowadzenia wywiadu, ale zwartą metodę jego analizy (Kaźmierska 2016: 61-65).

2 Pojęcie traumy przeszło do nauk humanistycznych i społecznych z języka medycznego. Pierwotnie oznaczało „ranę" lub „uraz” będące następstwem obrażenia ciała; następnie pojęcie to zostało zaadaptowane przez psychiatrię (zob. Saryusz-Wolska, Traba 2014: 501-503).

Wszystkie spośród 25 narracji opowiadały o antypolskiej akcji jako o wydarzeniu, które powodowało strach i przyśpieszało decyzję części polskiej ludności o wyjeździe w ramach powojennych migracji. 10 narracji biograficznych należało do ocalonych $\mathrm{z}$ antypolskiej akcji (zarówno rozmówcy z Polski, jak i z Ukrainy), czyli osób, które doświadczyły ataków, a niekiedy utraciły w nich część swoich rodzin.
} 
Na początku artykułu przedstawiam samo pojęcie traumy i różne sposoby jego rozumienia. Następnie, bazując na informacjach zdobytych podczas badań terenowych, zastanawiam się nad traumą biernych świadków żydowskiej zagłady. W kolejnym podrozdziale opisuję narracje o ocaleniu z antypolskiej akcji przeprowadzonej przez ukraińskich nacjonalistów na terenie Galicji Wschodniej w latach 1943-1945.

\section{Trauma jako pamięć ciała}

Pamięć sensoryczna jest jedną z podstawowych cech człowieka. Choć większość doznań zmysłowych na krótki okres pozostaje w pamięci, to tylko część z nich nie ulega trwałemu zapomnieniu, co wynika w znacznej mierze z ich intensywności oraz kontekstu doświadczenia. Jak stwierdza Michael Herzfeld, zmysły są nie tylko „oknami na świat”, ale także instrumentami zaprogramowanymi według określonych kodów, które dokonują przekładu doświadczenia cielesnego na kulturowo czytelne formy (Herzfeld 2004: 337). Interesującym zjawiskiem pamięci jest reminiscencja ${ }^{5}$, czyli mimowolne i bardzo szczegółowe przypomnienie sobie zdarzenia z przeszłości, które uważaliśmy za zapomniane. Wraz z obrazami, dźwiękami czy smakami odtwarzane są także emocje związane z tym wydarzeniem. W rzeczywistości wspomnienia zostają „uwolnione” nie tyle z powodu działania bodźca na jeden zmysł, lecz wskutek pewnej korelacji doznań zmysłowych określanej mianem synestezji, która przypomina nam o istnieniu i przeżywaniu konkretnego wydarzenia z przeszłości.

Informacje docierają do nas za pomocą zmysłów, które zapewniają poczucie autentyczności oraz bycia na miejscu zdarzenia - pozwalają widzieć coś „na własne oczy". Dzięki nim stajemy się naocznymi świadkami zajścia, przez co nasza opowieść staje się relacją, zostaje jej nadana wartość wiarygodności. Należy zaznaczyć, że człowiek staje się świadkiem na wskutek przekazania swoich wspomnień, które definiowane są jako świadectwo. Od świadka wymaga się obecności na miejscu wydarzenia i zmysłowej percepcji, to bowiem one sprawiają, że dany

4 Jako początek antypolskiej akcji Ukraińskiej Powstańczej Armii określa się wymordowanie mieszkańców wsi Parośla na Wołyniu 9 lutego 1943 roku. Celem akcji było usunięcie Polaków ze wszystkich ziem uznawanych przez ukraińskich nacjonalistów za etnicznie ukraińskie. W pierwszej kolejności atakowano przedwojenne województwo wołyńskie, natomiast na przełomie lat 1943-1944 akcja rozprzestrzeniła się na Galicję Wschodnią i ziemie dzisiejszej Polski. Grzegorz Motyka szacuje, iż w porachunkach polsko-ukraińskich w sumie w latach 1943-1947 zginęło, w wyniku ukraińskich działań, od 80 do 100 tys. Polaków, natomiast Ukraińców 10-20 tysięcy (Motyka 2009: 13).

${ }_{5}$ Reminiscencje - spontaniczne, mimowolne wspomnienia. Interesującym zjawiskiem jest efekt reminiscencji, czyli przypominanie sobie wspomnień z dzieciństwa i młodości w wieku powyżej 60 roku życia oraz wyraźna intensyfikacja tych wspomnień. Im starsza grupa badanych, tym wyraźniej zaznaczane jest wybrzuszenie reminiscencyjne, czyli posiadanie najwyraźniejszych i najdokładniejszych wspomnień z dzieciństwa i młodości (do 20-30 roku życia). Co specyficzne dla tych zjawisk, wydarzenia określane jako najsmutniejsze są najliczniejsze w bliskiej przeszłości lub teraźniejszości rozmówcy, natomiast jako najbardziej pozytywne są określane wydarzenia z okresu dzieciństwa lub młodości (Draaisma 2010: 100-101). 
człowiek staje się łącznikiem pomiędzy przeszłością a teraźniejszością (Saryusz-Wolska, Traba 2014: 476). „Bycie tam” pozwala pośredniczyć i przekazywać historię, a w konsekwencji - stać się świadkiem „tu i teraz”, mającym uprawnienia do opowiadania historii poprzez swoje doświadczenia (Wejland 2013: 121). Świadkowie historii z racji swoich przeżyć są stawiani moralnie wyżej, ponadto zazwyczaj są oni w podeszłym wieku i należą do odchodzącego pokolenia, dlatego ich opowieści traktowane są jako cenne i wyjątkowe (Kurkowska-Budzan 2011: 19). Sam charakter spotkania i świadectwa powoduje, że słuchacz na bazie empatii wierzy opowiadającemu ${ }^{6}$. Świadectwo wiąże się z pewnego rodzaju kredytem zaufania, który przydziela się słowom innego człowieka, a jednocześnie wymaga zachowania odpowiedniej ostrożności: na początku wierzymy w słowa drugiego człowieka, dopiero potem podajemy je w wątpliwość, uprzednio zdobywając dowody bądź nabierając niepewności (Ricoeur 2012: 2018).

Doświadczenie i pamięć są zespolone z doznaniami zmysłowymi, które stanowią ich podstawę, pośrednicząc między człowiekiem a otaczającym go światem. Psycholodzy uważają, że doznania sensoryczne są ulotne i nietrwałe, stąd też w terminologii psychologicznej ten rodzaj pamięci sensorycznej nazwany jest pamięcią ultrakrótką (Jagodzińska 2008: 118). Odmiennymi w charakterze są wspomnienia dotyczące zdarzeń tragicznych, które wiążą się z doświadczeniami granicznymi - są one bądź pamiętane bardzo dokładnie, wraz ze szczegółami, bądź też pozornie zapomniane poprzez proces wyparcia.

W kontekście traumy należy zaznaczyć także różnicę między pojęciami wydarzenia traumatycznego oraz doświadczenia traumatycznego. Pierwsze należy do przeszłości, można je datować, umieścić w kontekście historii, opisać; natomiast doświadczenie traumatyczne cechuje się nieuchwytnością, jest wywołane wydarzeniem z przeszłości, a zarazem odwołuje się do teraźniejszości, powoduje ponowne ożywianie emocji towarzyszących wydarzeniu. Jak pisze Dominick LaCapra: „W pamięci traumatycznej przeszłość nie jest po prostu zamkniętą i skończoną historią. Wciąż żyje w doświadczeniu i nawiedza czy mami jednostkę lub zbiorowość" (LaCapra 2009: 77).

Natomiast samo znaczenie pojęcia traumy jako urazu psychicznego wywodzi się z dyskursu psychologii i psychiatrii i jest definiowane ogólnie jako efekt zdarzenia tragicznego. Zdaniem Olgi Sakson-Obady trauma to

stan, w którym jednostka jest świadkiem lub została skonfrontowana $\mathrm{z}$ wydarzeniem, w którym ktoś poniósł śmierć, doznał poważnych obrażeń lub istniała groźba śmierci, poważnych obrażeń lub utraty integralności fizycznej. Osoba doświadczająca wydarzenie przeżywa intensywny lęk, bezradność i grozę (Sakson-Obada 2009: 62).

\footnotetext{
6 Bardzo ważnym aspektem wiary w autentyczność świadectwa są wypadki fałszywych świadectw, np. przypadek spisanych wspomnień dotyczących ocalenia z Holokaustu Benjamina Wilkomirskiego, które okazały się sfałszowane, czy książki Mishy Defonsceca pt. Misha: A Memorie of the Holocaust Years, które mówią o poszukiwaniu rodziców na Ukrainie przez żydowską dziewczynę, które zostały zdemaskowane przez dziennikarzy i okazały się wyłącznie literacką fikcją (zob. Wolska 2012: 196-207).
} 
Tak rozumiana trauma jest doświadczeniem druzgocącym, wymykającym się poza kontekst dotychczasowego życia, radykalnie je dezintegrującym; jest "awarią systemu", który próbuje sobie z nią poradzić za pomocą kompulsywnego odtwarzania wydarzenia traumatyzującego bądź działania (LaCapra 2009: 153). W przypadku pamięci traumatycznej przykładem tego jest afekt, czyli silne wrażenie powiązane z równie silnymi emocjami. W pamięci trudnej wśród "ocalonych" może on przyczynić się do mimowolnych napływów wspomnień (Saryusz-Wolska, Traba 2014: 554-555). Przypominanie sobie zdarzeń z dalekiej przyszłości z wyją̨tkową dokładnością i wyrazistością, niczym kadry filmowe, nazywane jest $\mathrm{w}$ terminologii psychologicznej pamięcią fleszową (flashbulb memory ${ }^{7}$ ). Zazwyczaj są to wydarzenia ważne, tragiczne dla jednostek, ale też całych społeczeństw.

W relacjach osób, które doświadczyły wojny, opowieści o wydarzeniach traumatycznych opierają się albo na ciszy oraz starannie dobranych słowach, albo przeciwnie - na chaotycznych, szybko wypowiadanych zdaniach. Lęki ocalonych "przyklejają się" do nich na zawsze, determinują ich życie, wchodzą w pamięć nawykową. Stają się piętnem, o którym chce się zapomnieć, ale jest to niemożliwe. Zapominanie jest naturalnym sposobem radzenia sobie z nieprzyjemnymi, obciążającymi wspomnieniami. Poprzez wyparcie wspomnień pozbywamy się bólu i chronimy zdrowie psychiczne. Ucieczka przed niewygodnymi wspomnieniami polega na nieprzyjmowaniu lub wyciszaniu pewnych faktów. Zapominanie nie jest tylko cechą charakterystyczną dla pamięci poszczególnego człowieka, ale także strategią radzenia sobie z przykrymi wspomnieniami w pamięci całych zbiorowości (Nowak 2011: 113-114). Ciało może być zatem nośnikiem pamięci nie tylko indywidualnej, ale także kulturowej, zwykle staje się medium niosącym pamięć o doświadczeniach trudnych, cierpieniu i bólu. Dotyczy wielu osób i ich doświadczeń, zazwyczaj w tym kontekście używana jest metafora blizny bądź piętna, które dotyka zbiorowość (Saryusz-Wolska 2009: 37-38). Przykładem tego jest pamięć o żydowskiej zagładzie, która w Polsce przez lata była tematem nieporuszanym, zakrywanym, wypieranym.

\section{Trauma świadka - obserwatorzy Holokaustu}

W każdej opowieści życia rozmówców - zarówno osób z Polski, jak i z Ukrainy - pojawiało się wspomnienie o Holokauście, jednak w większości rozmówcy używali określeń zastępczych, m.in. ,jak zabrali Żydów”, "gdy Żydzi zniknęli" bądź "gdy już nie było Żydów". Choć w rozmowach nie padały słowa "mord”, "zagłada", „śmierć", jednak sama zagłada Żydów pojawiała się bardzo często $\mathrm{w}$ „opowieściach zasłyszanych ${ }^{8 ”}$. Co zrobić z opowieściami rozmówców, w któ-

\footnotetext{
Pamięć fleszowa cechuje się wyrazistością i dokładnością, jednak może zawierać zniekształcenia.

8 Kaja Kaźmierska opowieści o losach rodziny, znajomych czy osób nieznanych określa mianem „historii innych”, w narracji pełnią one różne funkcje, m.in. mogą stanowić konstrukcje
} 
rych pojawiają się słowa „Żydziak”, „Żydek” czy też określeniach „Żydzi idący na rzeź jak barany"? Wydaje mi się, że takie sformułowania to pozostałości po przedwojennym antysemityzmie i wojennej „znieczulicy”. Jednak same opowieści rozmówców o zagładzie wiązały się z wyrazami empatii oraz litości nad ludzką tragedią. Łatwo jest dziś moralnie oceniać działania bądź bierność ludności w trakcie wojny. Wychwalać żołnierzy wyklętych, ganić brak reakcji wobec krzywdy ludzkiej w czasie terroru - nieważne, czy giną w nim Żydzi, Ukraińcy czy Polacy. Moim zdaniem tylko z taką refleksją można słuchać opowieści sprawców, biernych świadków i ofiar tych dramatycznych wydarzeń.

W efekcie II wojny światowej świat stracił niewinność i zupełnie przedefiniował swój porządek. Oprócz bezpośrednich sprawców i ofiar w wojnie uczestniczyło wielu innych ludzi, którzy pełnili rolę świadków, z bliska bądź z oddali obserwując "ostateczne rozwiązanie". Dopiero w latach 80. XX wieku dostrzeżono znaczenie postaci biernego obserwatora (bystander), który patrzył na zbrodnie, miał kontakt z poszkodowanymi, mógł lub nie mógł udzielić pomocy. Psycholodzy i psychiatrzy uznali, że również świadków może dotykać powojenna trauma, ponieważ w każdym człowieku zetkniętym z marnością życia ludzkiego i bezsensownością zła pozostają trwałe ślady (Orwid 2009: 93-94). Temat Holokaustu w większości narracji rozmówców ograniczał się do tragizmu mordów, czyli rozstrzeleń bądź znęcania się nad wychodzącymi do getta Żydami, niekiedy tylko dotyczył kontaktów z ukrywającą się ludnością. W dużej mierze były to opowieści o żydowskich sąsiadach i znajomych, czyli osobach znanych rozmówcom. Przy opowieści o ich śmierci bądź ocaleniu pojawiała się wzmianka o ich przedwojennym życiu, rodzinie czy statusie materialnym. We wszystkich relacjach pojawiała się opowieść o Holokauście - była to opowieść o terrorze, sposobach zabijania i okrucieństwie okupantów względem ludności żydowskiej.

Problem obserwatorów odnosił się przede wszystkim do kwestii pomocy lub bierności wobec Żydów w czasie okupacji niemieckiej. Większość sąsiadów bała się pomagać Żydom ze względu na ewentualne konsekwencje ze strony Niemców, dlatego w większości odmawiano udzielenia schronienia. Preteksty były rozmaite: zły sąsiad, sąsiad Volksdeutsch, gestapowiec, żona bądź krewni niezgadzający się na pomoc żydowskim sąsiadom itp. Wszystkie wymówki łączyło jedno: strach przed karą za ukrywanie Żydów (Ringelblum 1988: 77). Na terenach Generalnej Guberni groziła za to śmierć całej rodziny, co doprowadziło do sytuacji, w której Żydzi stali się źródłem biologicznego wręcz strachu, o czym opowiadali rozmówcy:

Przyszli [Żydzi] w nocy i prosili, żeby ich przechować... Siedzieli na stychu i w stajni. Tam im jeść nosiliśmy, nie długo, a trochę byli, bo potem tato się bał, że ktoś powie, dlatego byli parę dni. Oni płacili, dawali pieniądze, żeby tylko pobyć jeszcze dzień, dwa. Bo każdy chce żyć, z dziećmi byli (...). Poszli, bo ojciec

w tle, uzupełniać obraz wojny, czy też ukazywać możliwe zagrożenia płynące z działań wojennych - potencjalne scenariusze losu, który mógł przydarzyć się rozmówcy (Kaźmierska 1999: $38-45)$. 
bał się, że to ktoś powie... Oni takie dawali wszystkie takie jakieś płótna, taki kożuszek dali, to chodziłam do cerkwi [w nim]. Tak chcieli, żeby coś było z tego [że im się pomaga], żeby mogli przeżyć 9

Naziści starali się ukryć rozmiary eksterminacji Żydów, ofiary przewożono na stację kolejową ciężarówkami, akcję przeprowadzano na bocznicach, w jej czasie władza zakazywała ludziom wychodzenia z domu, nakazywała zamykanie okien i opuszczenie zasłon. Miejsca masowych egzekucji, np. Babi Jar, wybierano w taki sposób, aby znajdowały się w znacznym oddaleniu od domostw, zaś przyroda miała zagłuszać oddawane strzały (Hilberg 2007: 315). W ostateczności nie udało się jednak ukryć tych zbrodni przez lokalną ludnością, która obserwowała zagładę - ludzie nie musieli przyglądać się samej eksterminacji, by zauważyć „zniknięcie" Żydów. Jak opowiada jeden z rozmówców:

Raz wracam nad ranem ze Stanisławowa i słyszę wrzask setek ludzi, jest mróz. A ja nie widzę co tam się dzieje, [słyszę] strzały i strzały. A tam było koryto górskiej rzeki, która przez wieki wyżłobiła olbrzymią dolinę. Nie było widać, co się tam na dole dzieje, słychać tylko było. Ale kolega mieszkał bliżej i widział codziennie, co się tam dzieje. Miał okienko w dachu, obserwował z wysoka. Kilka tysięcy kobiet, dzieci, starców wygłodzonych zapędzono właśnie nad przygotowany dołek. Najpierw trzeba zdjąć odzież wierzchnią i do bielizny [się rozebrać] i czekać w kolejce na kule. Kula była wybawieniem po getcie. On jest wygłodzony, on jest schorowany, on jest zmarznięty, stoi czeka w kolejce na mrozie nago. Czeka, żeby dostać się na kładkę nad dołem i kulę, oby dobrą kulę dostał, oby od razu zabiła. I takie rzeczy się działy cały czas $^{10}$.

W opowieściach rozmówców było wiele zasłyszanych historii dotyczących chwili śmierci Żydów - niekiedy dotyczyły one anonimowych osób, niekiedy żydowskich sąsiadów znanych z imienia i nazwiska, ale zawsze były przekazywane jako „interesujące”, a zarazem ukazujące poziom okrucieństwa okupanta. Przykładem była opowieści jednej z rozmówczyń:

Jak Niemcy przyszli, tych Żydów wszystkich zabrali (...), zagnali w jedno miejsce i już później wywozili ich, takie forty były i okopy jeszcze z pierwszej wojny światowej, to tam przywozili i rozstrzeliwali Żydów i potem zasypywali. Mówili ludzie, że trzy dni ziemia się ruszała, że ręce nie były pozasypywane ziemią.... I opowiadali, że jeden takie pięcioletni Żydzik, gdzieś tam się schował [jak strzelali], wyszedł i płakał. I ci Niemcy zobaczyli, że ten Żydzik chodzi, płacze po tym placu, gdzie Żydów zagnali. (...) później opowiadali, że wybierali rzeczy [lepsze po Żydach] i resztę tych ciuchów [gorszych] palili, rzucali w ognisko i wzięli tego Żydziuka w to ognisko wrzucili, spalili go ${ }^{11}$.

9 Kobieta, ur. 1928 r., Obertyn, woj. stanisławowskie, ob. Ukrainy, wywiad w języku ukraińskim, tłumaczenie własne.

10 Mężczyzna, ur. 1929 r., Stanisławów, woj. stanisławowskie, ob. Polski.

11 Kobieta, ur. 1930 r., Brzeżany, woj. tarnopolskie, ob. Ukrainy. 
Mimo chęci zachowania tajemnicy przy akcjach eksterminacji Żydów plotki, „przecieki”, opustoszałe mieszkania, strzały w lesie czy miejsca zbiorowych grobów były jednoznacznym dowodem zagłady. Ci, którzy nie widzieli wyruszających do getta bądź na śmierć żydowskich sąsiadów, mieli dostęp do rzeczy i przestrzeni pożydowskich:

Jak już Niemcy przyszli, to zabrali wszystkich Żydów [w nocy]. Ja po coś poszłam do Obertyna, to [widziałam], to był straszny widok. Jak weszłam do Obertyna, to pod pierwszym domem [były] jakieś zabawki, jakieś rzeczy [porozrzucane]. Ci [ich] sąsiedzi widzieli co się stało, a my daleko mieszkaliśmy [od centrum miasteczka], to [nie wiedzieliśmy], że wszystkich Żydów już wywieźli. (...) Oni później te ubrania po tych Żydach w worki popakowali i tak sprzedawali. To w jednym worku na przykład były same spodnie, w drugim coś [innego], w każdym worku co innego było. Ponoć tam ludzie kupowali to, bo [wtedy] nie było rzeczy w sklepach ${ }^{12}$.

Rozmówczyni jako dziecko nie widziała samych egzekucji, jednak dostrzegała ich efekty w postaci rzeczy, które pozostały po Żydach. Przejęcie ich mienia nie było dla nieżydowskich sąsiadów przestępstwem. Słabość instytucji odpowiedzialnych za przestrzeganie porządku sprzyjała bezkarności. W relacjach rozmówców tylko przedmioty religijne były traktowane jako „naznaczone”, a zarazem świadczące o tragicznym losie ich właścicieli. W grabieży żydowskich rzeczy nie przeszkadzało ich pochodzenie, nawet Niemcy nie traktowali ich jako „skażonych niższością rasy”. Jak pisze Bożena Shallcross, „,za wyjątkiem przedmiotów związanych z kultem religijnym splądrowane rzeczy niemal niepostrzeżenie traciły swoje żydowskie nacechowanie i mogły być co najwyżej określane jako pożydowskie” (Shallcross 2012:12). Wzmianki o akcjach zajmowania mienia pożydowskiego pojawiają się jako „opowieści zasłyszane”, choć zazwyczaj rozmówcy traktują pozyskiwanie pożydowskich rzeczy jako coś oczywistego, tłumacząc sytuację deficytem dóbr w czasach wojennych.

Decyzja odnośnie do eksterminacji Żydów rozwijała się stopniowo. Na przełomie lipca i sierpnia 1941 roku wyznaczono pierwszą grupę, która miała zostać zlikwidowana - ludność żydowską mieszkającą na terenach wcześniej okupowanych przez ZSRR. Konsekwencją tego kroku była eliminacja Żydów z Generalnej Guberni. Dopiero kilka miesięcy potem Hitler podjął decyzję o wymordowaniu wszystkich europejskich Żydów (Żbikowski 2001: 6). Rozstrzeliwania galicyjskich Żydów odbywały się na taką skalę, że niektórzy dowódcy wojskowi słali protesty odnoszące się do sposobu prowadzenia akcji. Na opisywanych terenach masowe egzekucje przybierały zazwyczaj formę rozstrzeliwań poza miastem, bardzo często na kirkutach (Hryciuk 2005: 211-212). Dopiero od marca 1942 roku rozpoczęto transporty z gett do obozów zagłady (Schenk 2011: 244). Mieszkańcy

12 Kobieta, ur. 1932 r., Pod Wichami, woj. stanisławowskie, ob. Polski. Wywiad przeprowa-

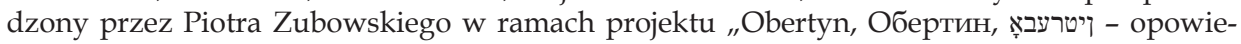
ści o życiu miasteczka przed 1956”, organizowanego przez Ośrodek „Pamięć i Przyszłość” we Wrocławiu. 
Galicji Wschodniej stali się mimowolnymi świadkami Holokaustu, niekiedy byli także wykorzystywani jako pomoc przy eksterminacji, o czym opowiada jeden z rozmówców:

Patrzę idzie jakaś procesja jakby na cmentarz, na pogrzeb, tam na górce za wsią, tam nowy cmentarz był. A to policja ukraińska prowadzi Żydów połapanych, przyprowadzili i mówią do Polaków: „dawajcie łopaty”, bo tam było kilku mężczyzn na cmentarzu, w tym mój stryjek. Żydom dali te łopaty i mówią: „kopcie tutaj dół”. A Polakom kazali siedzieć i stryj siadł i się popłakał. Taka dziewczyna jakieś siedemnaście lat, piękna Żydówka, w pięciu językach rozmawiała, prosi Ukraińców żeby jej nie zabijali, po butach, cholewach całowała, a on mówi: „Ydyte". Nogą trąca ją i stryjek bardzo to przeżywał, to kazali im [Polakom] iść za róg cmentarza, (...) poszli za winkiel i wtedy pach, pach, pach, powystrzelali Żydów. Przyszli Ukraińcy do tych Polaków: „Chodyty zakopaty”. Zakopać ich musieli ${ }^{13}$.

Istotą bycia świadkiem zagłady jest psychiczne odrętwienie, któremu może towarzyszyć gniew i agresja wobec słabszych. Poprzez podobne emocje i działania "ofiary” stają się niekiedy sprawcami, starając się odzyskać siły życiowe (Steinlauf 2001: 70-71). Dlaczego większość sąsiadów - świadków żydowskiej zagłady - pozostawała bierna? Psycholodzy społeczni uważają, że obojętność „reszty” w sytuacji ekstremalnej pozwala sprawcom na tłumaczenie i akceptację własnych działań jako słusznych (Staub 2006: 15-16). Kiedy jedni świadkowie pozostają bierni, zmniejsza się szansa na zaangażowanie także innych grup i jednostek $^{14}$. Im wcześniej świadkowie zaczynają działać, wyrażają sprzeciw wobec działań oprawców, tym bardziej prawdopodobne jest to, że ich słowa i czyny zdołają powstrzymać spiralę nienawiści albo choć zniwelować jej dotychczasowe skutki (Staub 2006: 33-35).

Obserwując ludzkie cierpienie, trudno jest powstrzymać wewnętrzny sprzeciw wobec działań jego sprawców. Aby ograniczyć uczucie współczucia dla innych, a zarazem winy za brak własnych działań, bierni obserwatorzy dystansują się od ofiar, postrzegają ich los jako zasłużony, doszukują się przyczyn „ukarania” winnych (Staub 2009: 30). W tym miejscu należy przyjrzeć się teorii kozła ofiarnego, który spełnia funkcję społecznego usprawiedliwienia - bierna jednostka lub grupa wierzy, że to właśnie ofiara zapoczątkowała problem i dlatego zasługuje na dyskryminację czy karę. W procesie tym zostają zastosowane odmienne standardy moralne dla grupy własnej i grupy dyskryminowanej (Frey, Rez 2009: 185). Z tej przyczyny wyjątkowymi opowieściami są te, które dotyczą pomocy Żydom, nawet gdy - jak w przypadku poniższej opowieści - jest ona minimalna:

13 Mężczyzna, ur. 1930 r., Dawidów, woj. lwowskie, ob. Polski.

14 Przykładem wpływu świadków na decyzje nazistów jest sytuacja Żydów w czasie wojny w Danii. Powszechne wsparcie dla Żydów wpłynęło na opóźnienie rozkazu o deportacji, co umożliwiło społeczności zorganizowanie ogromnej akcji pomocy oraz transportów, które wywiozły żydowską społeczność do neutralnej Szwecji. 
Widziałem, jak wieźli transport Żydów gdzieś ze Stanisławowa do obozu do Treblinki i widziałem, jak wyskakiwali przez okna Żydzi z transportu. Niemcy zbrojni byli i strzelali do nich. Tam dużo rannych było, ale dużo też pouciekało i był taki moment, że sam z kolegą podawałem Żydówce rannej wodę, ona po ukraińsku zaczęła prosić, a jak się zorientowała, że my Polacy to zaczęła po polsku mówić, że „wody, wody”. Myśmy jej przynieśli pić, ukraińska policja [tam była], to byli wredni bardzo ludzie i oni przyszli, jak myśmy wodę jej dawali. I jeden mówi: „Wylej to”. Mówi: „Hody” do tej Żydówki, a ona jęczy, bo płuca ma przestrzelone, jęczy. „Hody, szlah by tebe trafil, hody" - tak przeklinali. Pamiętam, że nam było szkoda kobiety, bo to człowiek, chcieli my dać wody, pomóc, to nie dali. [Ten ukraiński policjant] wziął tę wodę, wyrzucił nam to naczynie i wziął ją pod ręce i po tych torach ją ciągną $1^{15}$.

Podczas działań wojennych wszystkie procesy poznawcze człowieka koncentrują się na przetrwaniu, co powoduje jednocześnie stępienie wrażliwości na wszystko, co zewnętrzne. Wojenna schizofrenia polega na pęknięciu zasad normatywnych a zachowaniu rzeczywistych (Zaremba 2012: 121). Wzmocnione zostają więzi rodzinne, zawężone do najbliższej rodziny, która staje się centrum działań, koncentracją życia. Ten rodzaj skoncentrowania się na dobru rodzinnym przy równoczesnym odtrąceniu innych ludzi został nazwany „familiocentryzmem" (Zaremba 2012: 127). Ogrom terroru wobec innych oraz strach przed oprawcami powodował obojętność oraz bierność:

Wyszli ludzie z kościoła, z cerkwi, a Ukrainiec w mundurze milicjanta matkę siedmiorga dzieci żydowskich... Matka taka rozmamana kobieta. [On] każe się jej położyć, on miał jakieś 100 kilo żywej wagi i deptał po niej. Deptał. Zobaczcie kto on jest! Jaką on ma władzę! Były pomruki ze strony ukraińskiej i ze strony polskiej. Jak to tak? Na oczach ludzi, którzy wyszli z kościoła. Takie rzeczy były później na porządku dziennym proszę panią.

M.J.: Rozdeptat ją?

Tak. On ją zabił ${ }^{16}$.

Ludzie znieczulają się na okrucieństwo wojny, ponieważ wydaje się ona niemożliwa do zaprzestania. Współczucie to nietrwała emocja. Trzeba ją przekuć na działanie, inaczej obumiera. W trybie bierności również świadkowie ulegają przemianie, widząc cierpienie innych, zaczynają stopniowo akceptować prześladowania, racjonalizują, dystansują się, niekiedy nawet zaczynają być sprawcami cierpień (Staub 2009: 16).

Jedną z różnic w pamięci rozmówców z Polski i z Ukrainy było ukazywanie przesiedlonych Ukraińców jako sprawców - współwinnych Holokaustu na terenie Galicji Wschodniej. Uwypuklanie roli Ukraińców w zagładzie było swoistym podziałem ról - w relacjach przesiedleńców częściej wspominanymi sprawcami i podmiotami zadającymi ból byli Ukraińcy, natomiast Niemcy przedstawiani byli w większości jako ideolodzy zagłady, a nie jako czynni sprawcy. W relacjach

15 Mężczyzna, ur. 1930, Dawidów, woj. lwowskie, ob. Polski.

16 Mężczyzna, ur. 1929, Presowce, woj. tarnopolskie, ob. Polski. 
z Polski niewidoczna była rola ludności miejscowej w zagładzie (donosicielstwo, szabrowanie mienia pożydowskiego, które niewątpliwie miały miejsce zarówno wśród ludności polskiej, jak i ukraińskiej), o której z kolei wspominali rozmówcy z Ukrainy. Natomiast w relacjach rozmówców z Ukrainy nie pojawiają się kwestie kolaboracji i współodpowiedzialności organizacji partyzanckich ukraińskich w zagładzie ${ }^{17}$. W ocenie Anny Zapalec ukraińscy policjanci odegrali znaczącą rolę w zagładzie Żydów w dystrykcie Galicja, mieli oni wykonywać prace na rzecz III Rzeszy, w tym uczestniczyć zarówno w likwidacji gett, jak i w eksterminacji ludności żydowskiej (Zapalec 2018: 743). Winnymi zagłady w relacjach rozmówców z Ukrainy są Niemcy, natomiast w przypadkach donosicielstwa bądź szabru mienia pożydowskiego jest to raczej lokalna ludność, bez przynależności narodowościowej:

[Jak zlikwidowano getto] to nie było zniszczone, ludzie tam chodzili dolary szukali, obrazy, dzieci chodziły i coś znajdowały. Teraz dużo się pobudowało tam, ale kto coś powie, że znalazł cennego coś tam ${ }^{18}$.

Organizacje paramilitarne, takie jak OUN i UPA, niewątpliwie wspomagały akcję unicestwienia Żydów, część Ukraińców zasilała także oddziały SS, które brały udział w likwidacjach gett oraz masowych rozstrzelaniach. W relacjach z Ukrainy kwestia udziału jednostek ukraińskich w zagładzie jest przemilczana. Jednak dla rozmówców z Ukrainy winnymi zagłady są Niemcy, płynność tożsamości na tych terenach i pochodzenie większości rozmówców z rodzin mieszanych spowodowało, że Ukraińcem mógł być ojciec, brat bądź siostra. Ponadto wątek wykorzystywania jednostek narodowych na Ukrainie jest tematem trudnym i podobnie jak w Polsce dyskusyjnym. Natomiast w relacjach przesiedleńców postać „złego Ukraińca” zestawiona z „biernością Polaków” powoduje wybielenia postawy i próbę moralnego usprawiedliwienia bierności. Jest to przykład konfliktu tożsamościowego, w którym kwestia interpretacji faktów historycznych staje się punktem spornym, ponieważ jest ważnym elementem w budowaniu zbiorowej tożsamości (Stępka 2015: 138-139). W tym przypadku dotyczy to przesiedleńców-kresowiaków, w pamięci których oprócz Niemców i Rosjan sprawcami są także Ukraińcy - zarówno w przypadku Holokaustu, jak i w ramach antypolskiej akcji.

Bierność wobec cierpienia innych z czasem powoduje, że trudno podtrzymać wewnętrzny sprzeciw wobec działań sprawców - naturalnym procesem jest dystansowanie się od ofiar w celu ograniczenia poczucia winy i cierpienia

17 Jarosław Hrycak współpracę między Ukraińcami a niemieckim okupantem określa jako sojusz ukraińskich narodowców, którzy to podobnie jak III Rzesza mieli jako wrogów Rosję i Polskę. Dodatkowo Niemcy dla własnych celów wykorzystywali nastroje ukraińskich nacjonalistów i ich dążność do utworzenia niepodległego państwa. Dobrowolna współpraca przyjmowała dwie formy: formowanie jednostek wojskowych bądź pracy na rzecz okupanta w organach administracyjnych III Rzeszy. Ukraińskie jednostki wojskowe, np. dywizja SS Hałyczyna, powstały między ukraińskimi narodowcami a władzą niemiecką jako umowy polityczne (Hrycak 2000: 237).

18 Mężczyzna, ur. 1930, Czortków, woj. stanisławowskie, ob. Ukrainy. 
związanego z współodczuwaniem z ofiarami (Staub 2009: 30). W swoich badaniach Kaja Kaźmierska zwróciła uwagę, że często w przypadku opisów zagłady żydowskiej ukazywani są „,inni” winni zagładzie; w przypadku przesiedleńców z Galicji Wschodniej taką postacią -„czarnym charakterem” - byli Ukraińcy, a dokładniej ukraińska policja pomocnicza, której rękami Niemcy mieli wykonywać plan zagłady. W narracjach rozmówców z Ukrainy niechlubnymi sprawcami byli donosiciele, pomocnicy czy oddziały SS pomagające czynnie w eksterminacji Żydów złożone z ochotników, bez określania w opowieściach ich przynależności narodowej. Ponadto zarówno w relacjach rozmówców z Polski, jak i z Ukrainy pojawiają się przepowiednie żydowskie wieszczące tragedię, która w przyszłości miała dotknąć polską ludność. Przez rozmówców są one interpretowane jako zapowiedź antypolskiej akcji w latach 1943-1944:

A z Żydami... kto ich wyniszczył? Niemiec. Boże jak oni [ich] pobili! Niemiec! Oni uciekali wszystko zostawili to, co mieli w domach, co wzięli w ręki, to z tym poszli. [Ludzie] to tak mówili, że Żydzi Isusa Chrysta muczyły. A mówili [Żydzi nam]: „Nami ... zaczynały, a wami budut kinczyty”, (...) mówili, że „nami zaczęli, nas bili, a wami kończyć będą". To była pomsta od Boga. Chowali się Żydzi i u nas było też... dwóch Żyd i Żydówka: Abrom i Fejsi ${ }^{19}$.

\section{Trauma ofiary - ocaleni z antypolskiej akcji w 1943-1945 roku}

Prowadząc rozmowy, staram się szanować każdą z przedstawianych opowieści, każdego z rozmówców traktować jako specjalistę, eksperta od własnego życia. Nie poprawiać, nie dopytywać, gdy ktoś wyraźnie nie chce opowiadać o tragicznych wydarzeniach. To rozmówca ma w pełni decydować o tym, czy chce podzielić się opowieścią o cierpieniu, choć z doświadczenia wiem, że te wojenne doświadczenia zawsze „zostaną opowiedziane” w toku rozmowy, jakby musiały ujrzeć światło dzienne; są tak ważne, że bez nich nie zrozumie się historii życia rozmówcy. Doświadczenie ocalenia z czystki etnicznej jest ważne dla narracji biograficznej, ponieważ w jego czasie rozmówca musiał przedefiniować swoje życie. Nie chcąc przysparzać cierpienia rozmówcom, postanowiłam podczas badań kierować się powszechnie znaną regułą „Po pierwsze nie szkodzić” rozmową, pytaniami, wycofywać się, gdy wyczuje się dyskomfort spotkania. Podczas rozmów na Ukrainie prawdopodobnie po raz pierwszy spotkałam się z zachowaniami, jak się później dowiedziałam, syndromu pourazowego. Jedna z ocalonych z antypolskiej akcji na terenie Galicji Wschodniej w czasie opowieści zaczęła powtarzać zdania, delikatnie gibać się - jakby na chwilę „zatrzymała się w czasie”. Po kilku minutach, jakby nic się nie stało, powróciła do opowieści. Ze wspomnianych już względów przyjęłam strategię niepytania o antypolską akcję, wychodząc z założenia, że gdy ktoś będzie chciał podzielić się historią,

19 Kobieta, ur. 1928, Obrtyn, woj. stanisławowskie, ob. Ukrainy. Wywiad w części prowadzony w j. ukraińskim, w części po polsku. 
to sam o niej opowie. Wśród 25 rozmówców urodzonych w Galicji Wschodniej wszyscy w swoich wspomnieniach nawiązywali do antypolskiej akcji na tych terenach, 10 rozmówców doświadczyło antypolskiej akcji - byli oni ocalonymi z czystki etnicznej; pozostali słyszeli o atakach, widzieli spalone wsie, czuli strach przed napadami, jednak nie doświadczyli ich w swoich wsiach i miasteczkach.

Trauma zarówno w podejściu kulturowym, jak i z perspektywy psychologicznej jest związana z wydarzeniem szokującym, o niezrozumiałej dla człowieka naturze, wydarzeniem, na które nie jest się przygotowanym, dlatego powoduje zamknięcie się na normalny sposób funkcjonowania i przymus zdefiniowania siebie i swojego życia na nowo (Radstone 2000: 88). Osoby po przebytej traumie posiadają często pamięć utajoną, jednak jest ona zapisana w ciałach. Psycholodzy i psychiatrzy uważają, że w traumie i jej leczeniu ważne jest zrozumienie roli pamięci somatycznej i jej relacji z pamięcią utajoną. Ta pierwsza opiera się na działaniu sieci komunikacyjnej układu nerwowego, który przekazuje informacje pomiędzy mózgiem a miejscami w ciele. Całość doświadczenia ma swój początek w doznaniach zmysłowych, ponieważ dzięki zmysłom odbieramy świat, są one pierwszym przekazem kształtu rzeczywistości zewnętrznej. Wszystkie dane (uświadomione i nie), które odbieramy za pomocą zmysłów, są nieustannie przekazywane do mózgu, każde z nich jest doznaniem (Rothschild 2014: 62-63).

Teoria dotycząca traumy opiera się na opracowaniach relacji „zewnętrznego" $\mathrm{i}$ „wewnętrznego", nie tylko podczas samego wydarzenia, ale także jego konsekwencji oraz wspomnień. „Niestrawione” doświadczenie jest niezrozumiałe, staje się obszarem poza świadomością, czego przykładem są objawy symptomu zespołu stresu pourazowego (PTSD) (Radstone 2000: 87). Jest on dokładnym odtworzeniem doświadczenia w ramach marzeń sennych albo mimowolnych wspomnień, w czasie których powiela się wydarzenie traumatyczne, przez co staje się ono teraźniejszością, jest przeżywane ponownie. Mimo chęci wyparcia tych wspomnień ciało nie daje o nich zapomnieć. Psycholodzy uważają, że narracja-opowiadanie o doświadczeniu traumatycznym pomaga przepracować symptomy postraumatyczne - nieprzekazywalne doświadczenie zostaje „ubrane w słowa”, zapisane w języku, nie tylko w słowach, ale i milczeniu, wahaniach (Lacapra 2009: 159). Sama próba przekazania wspomnień powoduje, że muszą one być ujęte w ramach relacji z innymi przeżyciami, przez co stają się łatwiejsze do zaakceptowania. Część opowieści o ocaleniu cechuje się dokładnością, narracja jest kilkuzdaniowa, wypowiedziana wolno, zdania przerywane są chwilami milczenia, ma się wrażenie, że są „zbudowane z doznań”. Z kolei inni rozmówcy opowiadają szybko o doświadczeniach traumatycznych, „wyrzucają z siebie” kolejne zdania, śpieszą się z opowieścią. Przykładem jest fragment wypowiedzi o ocaleniu z antypolskiej akcji, w której rozmówca stracił rodzinę zamkniętą przez ukraińskich nacjonalistów w podpalonej stodole:

Zaczynam uciekać...Ale gdzie? Tu już krowy leżą spalone, przez krowę upadłem, zaczął ten dym mnie... W tym ogniu pali mnie się wszystko, twarz piecze. Rękami zaczynam zasłaniać sobie usta, żeby płomienie, żebym nie oddychał... I tak znów 
mam na myśli, że ten anioł stróż mnie wyrzucił stamtąd. Bo po prostu, tak mi się zdaje, że coś mnie złapało za plecy i na dwór mnie wyrzuciło z tego ognia! I ja leżałem na śniegu, zacząłem jeść śnieg, bo strasznie mnie w piersiach piekło. A tu twarz mam spaloną całkiem, głowę... Włosy to całkiem wiatr zwiał, popiół tylko, skóra została. A to było 24 marca w 1944 roku, a mróz był taki siarczysty mróz... Leżę na tym śniegu i jem ten śnieg, ale patrzę, idzie kto... Myślę, że [to ktoś z banderowców]... A to nasz, z sąsiadów jeden ${ }^{20}$.

Część osób ocalonych z wojennego terroru nie chce opowiadać o swoich doświadczeniach, wybiera milczenie, które ma przynosić spokój, uśpić pamięć, jednak częstokroć tragiczne wydarzenia nie dają o sobie zapomnieć. W warstwie nieuświadomionej pojawiają się objawy stresu pourazowego. Mimo braku pełnych i świadomie przywoływanych wspomnień ujawniają się one w koszmarach sennych, reminiscencjach i lękach, o których także wspominali rozmówcy. Ocalałych z antypolskiej akcji łączyło poczucie wielkiego strachu, które - jak sami wspominali - irracjonalnie objawia się do dzisiejszego dnia: „Ja do dziś słyszę, że ktoś puka do okien, a tak naprawdę nie puka chyba, tylko mi zostało z tego strachu $^{21 " \prime}$.

W ocenie psychiatrów i psychologów mimowolne wspomnienia mają prawdopodobnie na celu chronienie człowieka przed przykrymi odczuciami i negatywnymi emocjami (Jagodzińska 2008: 418). Dodatkowo dla rozmówców urodzonych w Galicji Wschodniej II wojna światowa była czasem dzieciństwa bądź młodości, czyli tych okresów życia, które pamięta się najdokładniej. Ważnym czynnikiem jest tutaj zatem również zjawisko zwane efektem reminiscencji, czyli mimowolne przypominanie sobie wydarzeń z dzieciństwa i młodości przez osoby w wieku powyżej 70 roku życia.

Pamięć dotycząca dzieciństwa i młodości pełna jest obrazów zatartych, opowieści, których nie jesteśmy pewni - nie wiemy, czy sami je zapamiętaliśmy, czy może znamy je tylko z opowieści naszych rodziców bądź dziadków. Przykładem jest zanotowana podczas badań opowieść o napadach nacjonalistów ukraińskich oraz próbach ratowania się rodziny:

[Z dzieciństwa] pamiętam, jak Ukraińcy idą, gdzieś tam się pali, gdzieś tam krzyczą ludzie, to jako dziecko zapamiętałam. Zapamiętałam, że jak się chowaliśmy do takiej piwnicy, z której szło się do następnej piwnicy i jeszcze dalej, aż było wyjście na ogród księdza, bo kościół był niedaleko i na tym ogrodzie była zrobiona taka grządka duża, którą się podnosiło do góry. (...) Myśmy uciekali stamtąd na powietrze. A okna na noc to się robiło takie okiennice z drewna i się zasłaniało. To takie przerażające sceny, to już pamiętam z dzieciństwa. Pamiętam, że mama, nas było pięcioro wtedy, to mama nam wieczorem każdemu dziecku jakiś kawałek chleba i kostkę cukru [czy] czekoladę dawała w taki tobołek, że jak się dziecko gdzieś zgubi [podczas ucieczki], żeby głodne nie było... Jak były już

20 Mężczyzna, ur. 1928, Zborów, woj. tarnopolskie, ob. Polski.

${ }^{21}$ Kobieta, ur. 1926, Palikrowy, woj. lwowskie, ob. Ukrainy. 
te napady, to wszyscy uciekali jak szaleńcy, [ten tobołek po to] żeby dziecko się gdzieś nie zawieruszyło ${ }^{22}$.

Jednak w większości wspomnienia traumatyczne były zapamiętywane przez rozmówców wyjątkowo dokładnie, stanowiły kadry pamięci. Niekiedy były pierwszymi dobrze zarysowanymi wspomnieniami z dzieciństwa. Natomiast przed nimi oraz po nich następowała luka chronologiczna. Przykładem jest rozpoczęcie opowiadania przez rozmówczynię, która po podaniu daty swoich urodzin od razu przeszła do najtragiczniejszych wydarzeń, jakie zapamiętała z okresy wojny:

Monasterzyska, urodziłam się 2 grudnia 1932 roku. Jako dziecko już znałam smak wojny, w 1940 roku... Druga sprawa to jeszcze trzeba było wrócić do tego, że u nas to później UPA było. To pamiętam jak dziś i nie zapomnę tego nigdy. Siedziałam na łóżku rozebrana w koszuli takiej na ramiączkach.... Wpada starsza siostra i mówi: „Mamo na naszej ulicy już mordują!”. Tak mama... [płacz - dop. M.J.] śnieg był, wiem tylko tyle i uciekali wszyscy do fabryki (...) Mama biegnie, a ja co chwila wpadam w śnieg. Goła dupa za przeproszeniem, mokra, śnieg wszędzie. (...) To był pierwszy napad Ukraińców na nasze ulice ${ }^{23}$.

W doświadczeniach wojennych wiele jest wydarzeń, które mogą powodować traumę. Część wspomnień rozmówców jest poszatkowana, składa się z poszczególnych kadrów i odczuć. Mimo to fragmentaryczne obrazy odciskają piętno na pamięci świadków tragicznych wydarzeń, nie dają o sobie zapomnieć, wiążą się z silnym ładunkiem emocjonalnym. Ocaleni są więc - jak pisze Peter Levine (2015: XIX) -,„tyranizowani" przez przeszłość.

Jak nas złapali i kazali nam wyjść [z kryjówki]. Było troszku Ukraińców we wsi, mieszanych rodzin dużo. Ci, co mordowali na koniach, to nieznani byli. Były takie ludzie ze wsi, pokazywali kto Ukrainiec, a kto Polak. [...] Karabinami otaczali i potem mordowali... Zaczęli nas dzielić. „Ta Polka, a ta Ukrainka”. Jak skończyli bić, strzelali, to ja nie chciałam patrzeć. Bo tam mózgi skaczą do góry i krew, dużo krwi, a ja klęknęłam za tymi ludźmi się schowałam. Mi się śni ten majdan, te plecy ludzi, krzyki i że ja klęczę i zamykam oczy²4.

Powracanie do traumatycznych przeżyć odbywa się nie tylko przez mimowolne wspomnienia, marzenia senne i lęk, który został w ocalonych, ale też poprzez kontakty z innymi uczestnikami tragicznych wydarzeń. Ocaleni zazwyczaj - o ile mają taką możliwość - spotykają się z tymi, którzy przeżyli te same wydarzenia. Z kolei osoby, które zostały bez swoich wspólnot, są skazane na samotność i niezrozumienie. Ich pamięć staje się przeciw-pamięcią, reprezentuje elementy odmienne od oficjalnej wersji zdarzeń. Przykładem takiej sytuacji jest częste spotykanie się kobiety ocalonej z antypolskiej akcji z jej sąsiadką, która

22 Kobieta, ur. 1928, Przemyślany, woj. tarnopolskie, ob. Polski.

23 Kobieta, ur. 1932, Monasterzyska, woj. tarnopolskie, ob. Polski.

24 Kobieta, ur. 1926, Palikrowy, woj. lwowskie, ob. Ukrainy. 
współpracowała z nacjonalistami ukraińskimi, wskazując im polskich mieszkańców wsi, tym samym skazując ich na śmierć:

I Ukraińce tak się nie chwalili, co się stało... Nie było takiego domu, w którym by nie było kogoś zabitego, z rodziny, z chaty. Kto się został, to został. [...] Te Ukrainki, co wybierały, to jedna jeszcze żyje. [Ta] co wybierała kto Polak. A ksiądz mnie pytał, jak my się spotykamy [z nią]? No spotykamy się. Wita się, to ja odpowiem i już. (...) Niech sobie żyje, Pan Bóg wie wszystko, na co mnie jej grzech na siebie brać, ona ma pełno grzechów, tyle krwi na rękach, tyle ludzi pomordowała ${ }^{25}$.

Spotkanie z kobietą, która pomagała sprawcom ataków, jest dla rozmówczyni codziennością, przypomina tragiczne chwile, zarówno ocalona, jak i ta, która pomagała oprawcom, pamiętają to samo wydarzenie, są jedynymi we wsi, które pamiętają doświadczenia z przeprowadzonej antypolskiej akcji. Mimo że pamiętaną z perspektywy różnych ról: świadka, który poprzez swoją działalność stał się sprawcą, i ofiary.

\section{Końcowe refleksje}

Tereny Europy Wschodniej są tymi, które doświadczyły największego okropieństwa dwóch totalitaryzmów, ponieważ zagłada, zsyłki, czystki etniczne, terror okupantów działy się w każdym miasteczku czy wsi. Największa liczba obozów zagłady znajdowała się na terenach dzisiejszej Polski, Ukrainy Zachodniej i Białorusi. Jak pisze Wojciech Kaute:

Na naszej «spokojnej» ziemi dokonano niewyobrażalnej zbrodni. Nie była to zbrodnia, jedna z wielu, jakich ludzkość doświadczyła do tysięcy lat. Ta zbrodnia to «końcowa stacja» człowieczeństwa, tak jak je pojmowała w swojej tradycji Europa. (...) W naszej przestrzeni człowiek stanął «oko w oko» wobec samego siebie, wobec wszelkiego zła, jakie w nim tkwi (Kaute 2012: 372).

Dla rozmówców dwa tragiczne wydarzenia: Holokaust i antypolska akcja były ściśle powiązane, w narracjach zagłada Żydów była zapowiedzią ataków nacjonalistów ukraińskich. O ile dla rozmówców Holokaust był wydarzeniem, które obserwowali, o tyle w przypadku antypolskiej akcji stali się oni „ofiarami” częstokroć w rozmowach dopowiadano „byliśmy ofiarami jak Żydzi”.

23 czerwca 1943 roku Dyrektor Instytutu Żydowskiego przy Światowym Kongresie Żydów Jacob Robinson potępił naród polski, gdy dowiedział się o tym, że cała ludność zamieszkała w getcie warszawskim została zamordowana w Treblince. Uważał, że naziści, dokonując zbrodni, byli pewni bierności Polaków: „W swojej ślepej nienawiści do Żydów stali się współodpowiedzialni za rzeź" (za: Hilberg 2007: 304). Tym sposobem oskarżył biernych świadków zagłady, zrównał ich ze sprawcami. Świadkowie obserwujący zagładę i nasilające się

25 Kobieta, ur. 1926, Palikrowy, woj. lwowskie, ob. Ukrainy. 
z czasem prześladowania jako grupa mają potencjalnie wiele możliwości działania, jednakże częstokroć pozostają bierni. Choć należy zaznaczyć, że stosunek Polaków do Żydów rozciągał się od wrogości i antysemityzmu po tolerancję czy wreszcie pomoc (Hilberg 2007: 297). Henryk Grynberg uważa, że dla Polaków, ale też Białorusinów i Ukraińców, Holokaust musiał być nie większym szokiem niż dla innych świadków, bo znajdowali się w epicentrum, to na tych terenach znajdowała się największa liczba obozów zagłady. Zdaniem Grynberga obserwatorzy do dziś noszą w sobie te emocje i niepokoje, które - nawet jeśli nie wprost - będą przekazywane z pokolenia na pokolenie (za: Tokarska-Bakir 2003: 208).

Holokaust i jego brutalność w pamięci osób urodzonych w II RP był zapowiedzią strachu Polaków przed atakami ukraińskich nacjonalistów. Konsekwencją mordowania Żydów był widok śmierci na szeroką skalę - śmierci masowej, brutalnej i bezsensownej. Widok ten spowodował proces oswajania się ze śmiercią i terrorem. Okupacja niemiecka z powodów obserwacji Holokaustu i doświadczenia antypolskiej akcji związana była z wzrastającym poczuciem strachu o własne życie. Strach zagościł na stałe w psychice mieszkańców Galicji do tego stopnia, że musieli oni wytworzyć pewien rodzaj obojętności, która była dla nich strategią przetrwania (Komoński 2013: 233). W tym kontekście w relacjach rozmówców Żydzi, podobnie jak Polacy, byli ofiarami, ich doświadczenie łączy cierpienie i odczuwanie strachu o własne życie. Choć niewątpliwie ukraiński nacjonalistyczny ruch był inspirowany faszystowską ideologią, której jednym z celów była eliminacja innych nacji z terenów „etnicznie ukraińskich”, to jednak te dwa wydarzenia mają odmienny charakter. Mimo to w pamięci rozmówców Polacy i Żydzi są stawiani na jednej szali (ofiar) ludobójstwa. W narracjach przesiedleńców strach i mordy na Żydach, które obserwowali Polacy, są zapowiedzią emocji odczuwanych przez rozmówców w czasie późniejszych napadów ukraińskich nacjonalistów. W relacjach z Polski częste ukazywanie Ukraińców jako sprawców Holokaustu - niekiedy postać „ukraińskiego policjanta” pojawiała się nawet częściej niż nazisty - uwypuklała winnych obydwu tragedii dziejących się w Galicji Wschodniej: eksterminacji Żydów, jak i antypolskiej akcji, które dla rozmówców były równoznacznymi tragediami i wiązały się z poczuciem ogromnego strachu. Z tej perspektywy w pamięci rozmówców Polacy i Żydzi są ofiarami tych wydarzeń, co powoduje, że problem moralny, jakim jest obserwacja eksterminacji Żydów, blaknie; z racji doświadczenia późniejszej antypolskiej akcji rola biernego świadka Holokaustu przeistacza się w rolę ofiary.

Rozmówcy pochodzący z Galicji Wschodniej doświadczyli traumy jako obserwatorzy żydowskiego Holokaustu, widzieli, czuli, słuchali o okropieństwach „ostatecznego rozwiązania kwestii żydowskiej”, ale też doświadczyli antypolskiej akcji, w której zginęły ich rodziny, znajomi, sąsiedzi. To antypolska akcja i wyjazd z Galicji Wschodniej jest centralnym doświadczeniem ich narracji biograficznej, natomiast Holokaust jest wydarzeniem brutalnym i bezkresnym złem, jednak w relacjach świadków stanowi „preludium” do opowieści o czystce etnicznej. O ile ocaleni z antypolskiej akcji, którzy wyjechali na tereny powojennej Polski, mieli możliwość spotkania się z innymi ocalonymi, o tyle ocaleni zamieszkujący 
nadal tereny Ukrainy są wyobcowani w swojej pamięci. Choć o antypolskiej akcji mówi się w ramach małych społeczności lokalnych Ukrainy Zachodniej, jednak podczas badań miałam wrażenie, że te opowieści są chętniej opowiadane obcym, którzy chcą słuchać i za chwilę wyjadą. O tragedii wśród miejscowej ludności się nie mówi, bo po prostu trzeba jakoś żyć w tym miejscu, co potwierdzają słowa jednego z rozmówców z Ukrainy: „Każdy we wsi wie, gdzie mordowali, ale o tym się nie mówi, to się po prostu pamięta i żyje". Niewątpliwie oba wydarzenia Holokaust i antypolska akcja - są dla opisywanych osób wydarzeniami traumatycznymi, łączącymi się z jednym z najważniejszych doświadczeń granicznych ich biografii, przywoływanymi ze szczegółami w każdej narracji biograficznej rozmówców zarówno z Ukrainy, jak i z Polski.

\section{Literatura}

Delasiński, T. (2014). Ludzkie, arcy(nie)ludzkie. Efekt afektu i aktualność podmiotu drugiej nowoczesności. W: Z. Budrewicz, R. Sendyka, R. Nycz (red.), Pamięć i afekty (s. 107-124). Warszawa: Wydawnictwo Instytutu Badań Literackich PAN.

Draaisma D. (2010). Fabryka nostalgii. O fenomenie pamięci wieku dojrzałego. Przeł. E. Jusewicz-Kalter. Wołowiec: Wydawnictwo Czarne.

Frey, D., Rez, H. (2009). Społeczeństwo i sprawcy. Warunki wstępne Holokaustu z perspektywy teorii kontroli. W: L.S. Newman, R. Erber (red.), Zrozumieć zagładę. Społeczna psychologia Holokaustu (s. 168-198). Przeł. M. Budziszewska. Warszawa: Wydawnictwo Naukowe PWN.

Gadamer, H.G. (1993). Prawda i metoda. Zarys hermeneutyki filozoficznej. Przeł. B. Baran. Kraków: Inter Esse.

Gruszczyński, W. (2016). Trauma a zespół stresu pourazowego. W: J. Jośko-Ochojska (red.), Medyczne i społeczne aspekty traumy (s. 147-170). Katowice: Śląski Uniwersytet Medyczny.

Herzfeld, M. (2004). Antropologia. Praktykowanie teorii w kulturze i społeczeństwie. Przeł. M.M. Piechaczek. Kraków: Wydawnictwo Uniwersytetu Jagiellońskiego.

Hilberg, R. (2007). Sprawcy, ofiary, świadkowie. Zagłada Żydów 1933-1945. Przeł. J. Giebułtowski. Warszawa: Wydawnictwo Cyklady.

Hrycak, J. (2000). Historia Ukrainy 1772-1999. Narodziny nowoczesnego narodu. Przeł. K. Kotyńska. Lublin: Instytut Europy Środkowo-Wschodniej.

Hryciuk, G. (2005). Przemiany narodowościowe i ludnościowe w Galicji Wschodniej i na Wołyniu w latach 1931-1948. Toruń: Adam Marszałek.

Jagodzińska, M. (2008). Psychologia pamięci. Badania, teorie, zastosowania. Gliwice: Helion.

Kaute, W. (2012). Kiedy my żyjemy... Holokaust a polskie doświadczenie przestrzeni. W: W. Pawluczuk, S. Zagórski (red.), Miejsca święte, miejsca przeklęte. Polskie doświadczenie przestrzeni (s. 369-378). Łomża: Oficyna Wydawnicza "Stopka”.

Kaźmierska, K. (1999). Doświadczenia wojenne Polaków a kształtowanie tożsamości etnicznej. Analiza narracji kresowych. Warszawa: Wydawnictwo IFiS PAN.

Kaźmierska, K. (2016). Wywiad narracyjny - technika i pojecie analityczne. W: R. Dopierała, K. Waniek (red.), Biografia i wojna. Metoda biograficzna w badaniu procesów społecznych. Wybór tekstów (s. 61-72). Łódź: Wydawnictwo Uniwersytetu Łódzkiego. 
Komoński, E. (2013). Ludność polska Wołynia i Galicji Wschodniej wobec mordów ukraińskich w latach 1943-1944. Antropologia strachu, Studia z dziejów Rosji i Europy Środkowo-Wschodniej, 48, 231-238.

Kurkowska-Budzan, M. (2011). Informator, świadek historii, narrator, -kilka wątków epistemologicznych i etycznych oral history. Wrocławski Rocznik Historii Mówionej, I, 9-34.

LaCapra, D. (2009). Historia w okresie przejściowym. Doświadczenie, tożsamość, teoria krytyczna. Przeł. K. Bojarska. Kraków: Universitas.

Levine, P.A. (2015). Trauma and Memory. Brain and body in a search for the living past, Berkeley: North Atlantic Books.

Motyka, G. (2009). Wkręu "Eun w Bieszczadach”. Szkice o najnowszej historii polskich Bieszczad. Warszawa: Oficyna Wydawnicza RYTM.

Nowak, J. (2011). Społeczne reguły pamiętania: antropologia pamięci zbiorowej. Kraków: Nomos. Orwid, M. (2009). Trauma. Kraków: Wydawnictwo Literackie.

Radstone, S. (2000). Screening Trauma: Forrest Gump, Film an Memory. W: S. Radstone (ed.), Memory and methodology (s. 79-110). Oxford-New York: Berg.

Ricoeur, P. (2012). Pamięć, historia, zapomnienie. Przeł. J. Margański. Kraków: Universitas.

Ringelblum, E. (1988). Stosunki polsko-żydowskie w czasie drugiej wojny światowej. Warszawa: Wydawnictwo Czytelnik.

Rokuszewska-Pawełek, A. (2002). Chaos i przymus. Trajektorie wojenne Polaków-analiza biograficzna, Łódź: Wydawnictwo Uniwersytetu Łódzkiego.

Rothschild, B. (2014). Ciało pamięta. Psychofizjologia traumy i terapia osób po urazie psychicznym. Przeł. R. Andruszko. Kraków: Wydawnictwo Uniwersytetu Jagiellońskiego.

Sakson-Obada, O. (2009). Pamięć ciała. Ja cielesne w relacji przywiązania i traumie. Warszawa: Difin.

Saryusz-Wolska, M. (2009). Wprowadzenie. W: M. Saryusz-Wolska (red.), Pamięć zbiorowa i kulturowa. Wspótczesna perspektywa niemiecka (s. 7-38). Kraków: Universitas.

Saryusz-Wolska, M., Traba, R. (red.). (2014). Modi memorandi. Leksykon kultury pamięci. Warszawa: Scholar.

Schenk, D. (2011). Noc morderców. Kaźń polskich profesorów we Lwowie i holokaust w Galicji Wschodniej. Przeł. P. Zarychta. Kraków: Wysoki Zamek.

Sendyka, R. (2014). Nowe przestrzenie humanistyki: pamięć, afekty i inne terytoria. W: Z. Budrewicz, R. Sendyka, R. Nycz (red.), Pamięć i afekty (s. 15-19). Warszawa: Wydawnictwo Instytutu Badań Literackich PAN.

Shallcross, B. (2012). Rzeczy i zagłada. Kraków: Universitas.

Shore, M. (2012). Smak popiołów. Dziedzictwo totalitaryzmu w Europie Wschodniej. Przeł. M. Schuster. Warszawa: Świat Książki.

Staub, E. (2009). Psychologia świadków, sprawców i ratujących bohaterów. W: L.S. Newman, R. Erber (red.), Zrozumieć zagładę. Społeczna psychologia Holokaustu (s. 15-42). Przeł. M. Budziszewska. Warszawa: Wydawnictwo Naukowe PWN.

Steinlauf, M. (2001). Pamięć nieprzyswojona. Polska pamięć zagłady. Przeł. A. Tomaszewska. Warszawa: Wydawnictwo Cyklady.

Stępka, M. (2015). „Konflikt ukryty” a integracja europejska. Trudne relacje polsko-ukraińskie w perspektywie społeczeństwa pogranicza, W: D. Niedźwiedzki (red.), Pamięć i integracja społeczna na pograniczach. Przypadek pogranicza polsko-niemieckiego i polsko-ukraińskiego (s. 138-139), Kraków: Zakład Wydawniczy.

Straś-Romanowska, M. (2010). Psychologia wobec małych i wielkich narracji. W: M. Straś-Romanowska, B. Bartosz, M. Żurko (red.), Psychologia matych i wielkich narracji (s. 21-40). Warszawa: Eneteia Wydawnictwo Psychologii i Kultury.

Tokarska-Bakir, J. (2003). Rzeczy mgliste. Eseje i studia. Sejny: Pogranicza. 
Wejland, A.P. (2013). Antropolog i pojęcie świadectwa. O niektórych pułapkach w badaniu terenowym. W: I.B. Kuźma (red.), Tematy trudne. Sytuacje badawcze (s. 111-142). Łódź: Wydawnictwo Uniwersytetu Łódzkiego.

Wolska, D. (2012). Odzyskać doświadczenie. Sporny temat humanistyki wspótczesnej. Kraków: Universitas.

Zapalec, A. (2018). Powiat złoczowski. W: B. Engelking, J. Grabowski (red.), Dalej jest noc. Losy żydów w wybranych powiatach okupowanej Polski (s. 623-750), t. 1, Warszawa: Stowarzyszenie Centrum Badań nad Zagładą Żydów.

Zaremba, M. (2012). Wielka trwoga. Polska 1944-1947. Ludowa reakcja na kryzys. Kraków: Wydawnictwo Znak.

Żbikowski, A. (2001). Wstęp. W: F. Katzmann, Rozwiązanie kwestii żydowskiej w dystrykcie Galicja. Przeł. J. Pawłowska, oprac. A. Żbikowski (s. 5-12). Warszawa: Instytut Pamięci Narodowej.

\section{SUMMARY}

Trauma of Bystanders, Trauma of Victims?

Holocaust and Massacres of Poles in memory of people born in Eastern Galicia

The article aims to show the trauma bystanders as well as the trauma victims of the World War 2. Based on the examples taken from field research conducted in Poland and Ukraine, the author presents various aspects of wartime trauma and its effects. Biographical narratives of people born in the 1930s in Eastern Galicia describe the trauma bystanders of Holocaust as well as the trauma victims of Massacres of Poles in Eastern Galicia carried out by Ukrainian nationalists in 1943-1945.

Keywords: trauma, victims, bystander, Massacres of Poles, Holocaust, Eastern Galicia 